\title{
Evaluating the Benefits of a Streamlined Refinance Program
}

\section{Kristopher Gerardil}

Federal Reserve Bank

of Atlanta
Lara Loewenstein

Federal Reserve Bank

of Cleveland
Paul Willen

Federal Reserve Bank

of Boston
CENTER FOR QUANTITATIVE

ECONOMIC RESEARCH

CENTER FOR HUMAN

CAPITAL STUDIES

CENTER FOR FINANCIAL INNOVATION AND STABILITY

\section{CENTER FOR HOUSING}

AND POLICY

\section{Summary:}

Mortgage borrowers who have experienced employment disruptions as a result of the COVID-19 pandemic are unable to refinance their loans to take advantage of historically low market rates. In this article, we analyze the effects of a streamlined refinance ("refi") program for government-insured loans that would allow borrowers to refinance without needing to document employment or income. In addition, we consider a cash-out component that would allow borrowers to extract some of the substantial amount of housing equity that many have accumulated in recent years.

\section{Key findings:}

1. Many borrowers could significantly lower their rates through a streamlined refinance program. The current market rate for a 30-year fixed-rate loan is 115 basis points (bps) lower than the rate that the average Fannie Mae and Freddie Mac borrower pays and 91 bps lower than the rate paid by the average Ginnie Mae borrower.

2. Most borrowers have accumulated substantial amounts of equity in their homes. The median Fannie/Freddie borrower has a mark-to-market loan-to-value (LTV) of 50 percent, while the median Ginnie borrower has a LTV of 65 percent.

3. A streamlined refi program that held mortgage balances constant would lower monthly payments for the average Fannie/Freddie (Ginnie) borrower by approximately $\$ 280$ (\$200) while decreasing default risk by 44 percent (38 percent).

4. A streamlined cash-out program that held payments constant and allowed loan balances to increase would generate an average of $\$ 54,000(\$ 35,000)$ for Fannie/ Freddie (Ginnie) borrowers while increasing default risk by 31 percent (26 percent).

5. A hybrid program that holds default risk constant would reduce average payments for Fannie/Freddie (Ginnie) borrowers by \$96 (\$93) and generate approximately $\$ 38,000(\$ 23,000)$ in cash-out.

JEL classification: G28, G51, R38

Key words: mortgage, refinance, cash-out, COVID-19

https://doi.org/10.29338/ph2020-08 


\section{Evaluating the Benefits of a Streamlined Refinance Program}

Summary: Mortgage borrowers who have experienced employment disruptions as a result of the COVID-19 pandemic are unable to refinance their loans to take advantage of historically low market rates. In this article, we analyze the effects of a streamlined refinance ("refi") program for government-insured loans that would allow borrowers to refinance without needing to document employment or income. In addition, we consider a cash-out component that would allow borrowers to extract some of the substantial amount of housing equity that many have accumulated in recent years.

JEL Classification: G28, G51, R38

Key words: mortgage, refinance, cash-out, COVID-19

\section{About the Authors:}

Kristopher Gerardi is a financial economist and adviser in the Research Department of the Federal Reserve Bank of Atlanta.

Lara Loewenstein is a research economist in the Research Department of the Federal Reserve Bank of Cleveland.

Paul Willen is a senior economist and policy adviser in the Research Department of the Federal Reserve Bank of Boston.

Acknowledgments: The authors thank Bob Avery, Daniel Cooper, Andreas Fuster, Nikolay Gospodinov, Maria Luengo-Prado, Giovanni Olivei, and participants in the MIT-Urban Housing Finance Call and an online workshop at the Federal Housing Finance Agency for helpful comments and suggestions. They especially thank Daniel Sexton for excellent research assistance. The views expressed here are the authors' and not necessarily those of the Federal Reserve Bank of Atlanta or the Federal Reserve System. Any remaining errors are the authors' responsibility.

Comments to the authors are welcome at Kristopher.Gerardi@atl.frb.org, Lara.Loewenstein@cle.frb.org, orPaul.Willen@bos.frb.org. 
The COVID-19 pandemic has resulted in lower interest rates in general and lower mortgage interest rates, in particular. The 3.15 percent 30 -year fixed rate recorded in the Freddie Mac survey for the week of May 25, 2020, was the lowest since the survey began in 1971. Unfortunately, another effect of the pandemic has been unprecedented job losses: From February through May, employment fell by almost 20 million jobs, and the share of adults with jobs fell from 61.1 percent to 52.8 percent. Since a stable source of income is a key component of most successful loan applications, many American families cannot take advantage of low mortgage rates. However, American households are unusually well positioned for credit access with respect to another key underwriting variable: equity. As figure 1 shows, American households have almost $\$ 20$ trillion in equity or almost 1.2 times their annual disposable income. It is easy to see why a lender would be reluctant to make a loan to a

Figure 1. Aggregate Housing Equity.

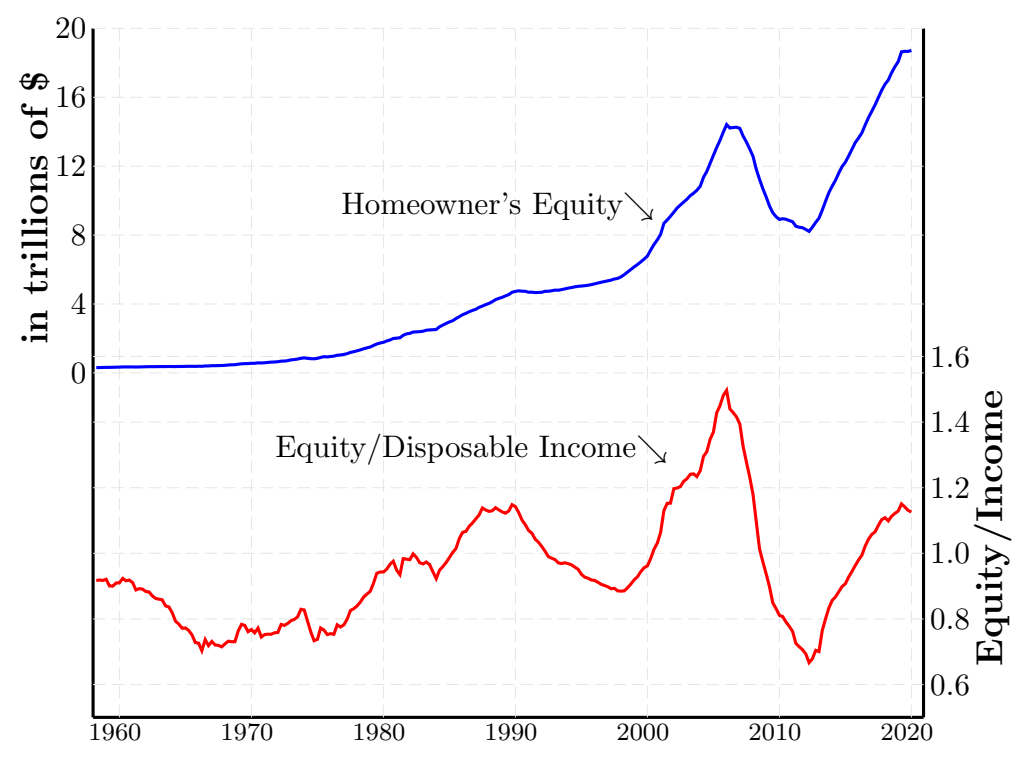

Notes: Homeowners' Equity is taken from the Flow of Funds, while disposable income here is Personal Disposable Income from NIPA.

new borrower who is furloughed or unemployed. But doing so for an existing borrower, with a mortgage that is already on the books, is a different story. In fact, one can reasonably argue that as long as the new monthly payment drops, the new mortgage is at lower risk of default compared with the previous loan. Empirical evidence shows that indeed, a decline in monthly mortgage payments, all else being equal, significantly reduces the risk of mortgage default (Fuster and Willen, 2017, Di Maggio et al., 2017, and Abel and Fuster, 2019). This lower risk is especially true for loans insured by Fannie Mae/Freddie Mac, the Federal Housing Administration (FHA), or the US Department of Veterans Affairs (VA), organiza- 
tions that are the focus of this paper. Since these agencies already provide insurance against default risk, allowing lenders to refinance existing loans and then purchasing and insuring the new loans would reduce the risk of their portfolios.

In this article, we analyze the potential effects of a streamlined refinance program with zero closing costs 1 that would allow borrowers with existing loans that are insured by the federal government to take advantage of lower rates and reduce their monthly mortgage payments, without needing to verify their employment and/or income. There is precedent for such a program. The Home Affordable Refinance Program (HARP), which was implemented by the Federal Housing Finance Agency (FHFA) in early 2009 in response to the global financial crisis (GFC), was predicated on similar logic. While not verifying employment or income might seem risky, as mentioned above, refinances are solely for existing borrowers who already present a default risk and for whom lower payments would reduce that risk. Furthermore, given that we do not know how long people will remain furloughed or unemployed, a refinance would also have the additional benefit of reducing a borrower's mortgage payments for the remaining term of the loan, providing them with a more extended form of relief than a six- to twelve-month forbearance.

We begin with a simple, streamlined refinance program, akin to HARP, and measure the change in mortgage rates, monthly payments, and default risk of borrowers with loans insured by Fannie Mae, Freddie Mac, and Ginnie Mae. Many of these borrowers, as of March 2020 (our most current month of data) had loans with interest rates well above current market levels. Assuming that Fannie and Freddie borrowers refinance into loans with the same remaining maturity length as their current mortgages, 2 we find that the median borrower would be able to lower their rate by more than $90 \mathrm{bps}$, which would correspond to a decrease of approximately $\$ 80$ in their monthly payment. Allowing borrowers to fully recast their loan terms would result in even larger effects, as the median payment would fall by about $\$ 230$. The payment decreases are slightly smaller for the median Ginnie Mae borrower, at $\$ 58$ and $\$ 162$, respectively. We then use estimates from Fuster and Willen (2017) to map the payment changes into effects on the probability of default and find that the default hazard for the median Fannie Mae and Freddie Mac (Ginnie Mae) borrower would fall by 17 percent (14 percent) when the loan maturity is kept constant, and 37 percent (33 percent) if the maturity is recast.

\footnotetext{
${ }^{1}$ HARP allowed borrowers without enough cash to cover closing costs to roll those costs into their new loan (see https://www.fhfaoig.gov/Content/Files/EVL-2013-006.pdf). Assuming zero closing costs is a simplifying assumption, but it is not an unreasonable one since they are typically a relatively small percentage of the principal balance. Rolling closing costs into principal balances would slightly increase monthly payments and reduce potential cash-out payments by 2 percent to 5 percent.

${ }^{2}$ This is not uncommon. For example, Quicken Loans offers a choice of term that allows borrowers to match their current remaining loan term. See https://www.quickenloans.com/home-loans/custom-mortgag e-yourgage.
} 
While these payment reductions are nontrivial, they are unlikely to be of much assistance to borrowers experiencing severe income disruptions from job losses. Those borrowers likely need significantly more relief. One viable option for distressed borrowers would be to tap into their housing equity. The combination of large equity cushions and low interest rates should provide a cheap source of secured credit for financially distressed borrowers to smooth their consumption during the pandemic, either through cash-out refinances or home equity lines of credit (HELOCs). However, many borrowers face the same impediment to accessing home equity as they do to obtaining lower rates: the inability to show a stable source of income.

Therefore, we extend our analysis of a streamlined refinance program to include a cashout component. Specifically, we consider two types of cash-out schemes. The first scheme allows borrowers to withdraw housing equity subject to two limits: The monthly payment cannot increase, and the loan-to-value (LTV) ratio of the new loan cannot exceed 90 percent. We estimate that the median Fannie Mae and Freddie Mac borrower would be able to take approximately $\$ 13,000$ in cash-out payments holding the loan maturity constant at its current level and more than $\$ 45,000$ by recasting the mortgage maturity to its original level. The cash-out amounts are lower for Ginnie borrowers - $\$ 8,000$ and $\$ 30,000$, respectively - since they do not have as much housing equity 3 Although many financially distressed borrowers would undoubtedly benefit from the increased cash flow of such a policy, on average it would increase the default risk of the government's loan portfolio, as the increased loan balances would more than offset the interest rate declines, resulting in higher monthly mortgage payments. We estimate that under this plan default rates would increase about 30 percent (that is, by a factor of 1.3).

Thus, in a second scheme, we reduce the cash-out amount to ensure that the default risk of the new loan equals the default risk of the current loan (while also maintaining the 90 percent LTV cap). We refer to this as the "iso-default" level of cash-out, since it is the amount of cash that can be extracted without changing the default risk of the loan. Under this policy, the median Fannie Mae and Freddie Mac (Ginnie Mae) borrower could take out approximately $\$ 9,000(\$ 6,000)$ holding the loan maturity constant at its current value and more than $\$ 30,000(\$ 18,000)$ by recasting the maturity of the loan to its original level.

One way to view such a refinance policy is as an alternative to forbearance, the primary relief option currently available to borrowers. The Coronavirus Aid, Relief, and Economic Security (CARES) Act, which was passed by Congress in March 2020 to address COVID19 economic disruptions, gives homeowners with federally insured mortgages the option to forbear or defer their mortgage payments for as long as 12 months. Through the end of May

\footnotetext{
${ }^{3}$ On average, Ginnie Mae borrowers have higher LTVs at origination. Of loans outstanding as of February 2020, the median origination LTV for Ginnie Mae loans was 96, compared with 75 for Fannie Mae/Freddie Mac borrowers.
} 
2020, more than 8 percent of mortgage borrowers had signed up for a forbearance plan 4 , but substantially fewer had chosen to actually forgo making their monthly payment. According to the McDash Flash Forbearance Tracker, 46 percent of borrowers in forbearance in April and 22 percent of borrowers in May made their monthly payments. 5

A streamlined refi program has advantages and disadvantages compared with forbearance. Administrative costs of forbearance are minimal, whereas refinances can be expensive, although in theory the nature of streamlined refinance should reduce those costs. On the other hand, simply signing up for a forbearance plan can make it impossible for a borrower to refinance 6 Borrowers in forbearance cannot take advantage of low interest rates until forbearance ends, meaning that they will accrue interest at a high rate and run the risk that when they are ready to refinance, rates will have returned to pre-crisis levels. A borrower who signs up for forbearance but chooses to continue making payments may get the worst of both worlds: no relief and no ability to take advantage of low rates. Another issue with forbearance is that borrowers appear to have a strong aversion to skipping monthly payments, even when it is in their interests to do so.7 Some borrowers would do a cash-out refinance but eschew forbearance for moral reasons, even though the economic implications are similar.

\section{Background and Data}

\section{HARP and Other Government Streamlined Refinances}

HARP was announced by the U.S. Department of Treasury in March 2009 and applied to loans that were guaranteed by Fannie Mae or Freddie Mac before June 2009. The purpose was to allow homeowners who had mark-to-market LTVs above 80 percent to take advantage of low prevailing mortgage rates. Before HARP, borrowers with LTVs between 80 percent and 100 percent could refinance into a Fannie Mae/Freddie Mac loan only by obtaining private mortgage insurance, while borrowers with negative equity (that is, LTVs above 100 percent) were unable to refinance at all. There were a few eligibility requirements of HARP. Borrowers had to be current on their payments, with no late payments in the previous six months, and no more than one late payment in the previous year. An LTV cap was

\footnotetext{
${ }^{4}$ According to a weekly survey run by the Mortgage Bankers' Association (MBA), 8.5 percent of borrowers were in forbearance plans as of May 31: https://www.mba.org/2020-press-releases/june/share-of-m ortgage-loans-in-forbearance-increases-to-853. However, that includes forbearance on private market loans. Forbearance rates on Fannie Mae/Freddie Mac (Ginnie Mae) loans was at 6.4 percent (11.83 percent).

${ }^{5}$ See https://www.blackknightinc.com/blog-posts/number-of-forbearance-plans-falls-for-first-time-sin ce-crisis-began/.

${ }^{6}$ See https://www.cnbc.com/2020/05/12/coronavirus-some-homeowners-getting-mortgage-bailouts-bymistake.html.

${ }^{7}$ See Gerardi et al. (2018).
} 
initially set at 105 percent, but that cap increased to 125 percent in September 2009 and was completely eliminated in June 2012. Finally, borrowers were allowed to use the program only once 8

The underwriting process for HARP also evolved over time; manual underwriting requirements were eliminated, and documentation for borrower income was relaxed in 2012. In addition, Fannie Mae/Freddie Mac acquisition fees (loan-level pricing adjustments) were substantially decreased. Finally, representations and warranties were eliminated in January 2013, so the originator had no liability in the event of a subsequent default. Altogether, approximately 3.5 million loans were refinanced through HARP before the program ended in 2018. There is evidence that the program had beneficial effects by reducing mortgage default and increasing consumer spending (Agarwal et al. (2015), Karamon et al. (2017), and Abel and Fuster (2019)). Although HARP applied only to Fannie Mae and Freddie Mac loans, the two principal Ginnie Mae loan programs - the Federal Housing Administration (FHA) and Department of Veteran Affairs (VA) - have had their own streamlined refinance programs for some time. FHA began its Streamline Refinance (SLR) program in 1982.9 Like HARP, the SLR does not place any limits on the borrower's mark-to-market LTV, so borrowers with negative equity can use the program. Unlike HARP, the SLR does allow borrowers to extract equity, however the cash-out amount is capped at $\$ 500$. The program traditionally did not require updated credit report information, verification of income and assets, or an updated property appraisal. However, a major policy change in 2009 required SLR borrowers to document employment and income 10

The VA streamlined refinance program is called the interest rate reduction refinance loan (IRRRL). The IRRRL program functions similarly to the SLR. It does not allow cash-out payments, but like the SLR, it allows borrowers to roll closing costs ("funding fee") into the loan balance 11

\section{Current Refinance Environment}

Figures 1 and 2 illustrate that borrowers have big incentives to refinance right now. Figure 2 shows that the weighted average coupon (WAC) on an existing agency mortgage is still over 4 percent, or more than 3 percentage points higher than the return on a 10-year constantmaturity Treasury (CMT) bond. The gap between the WAC and 10-year CMT has not been

\footnotetext{
${ }^{8}$ The official HARP announcement and links to additional program details can be found here: https:// www.treasury.gov/press-center/press-releases/Pages/200934145912322.aspx.

${ }^{9}$ See https://www.hud.gov/sites/documents/82-23ML.TXT for formal announcement of the program.

${ }^{10}$ Another change prevented borrowers with high LTVs from rolling closing costs into the balance of the new loan. For more details on the SLR and an analysis of these policy changes on borrower outcomes, see deFusco and Mandragon (deFusco and Mandragon).

${ }^{11}$ Further details can be found at https://www.va.gov/housing-assistance/home-loans/loan-types/intere st-rate-reduction-loan/.
} 
that big since early in the last decade, in the immediate aftermath of the financial crisis. In addition, Figure 1 shows that homeowners have almost $\$ 20$ trillion in equity in their homes. Though large in absolute terms, equity is also high relative to income. To be sure, it has not reached the heights attained in the last cycle, however, homeowners have had this much equity relative to income on only a few occasions over the previous 60 years. Figure 3 ,

Figure 2. Incentives to Refinance

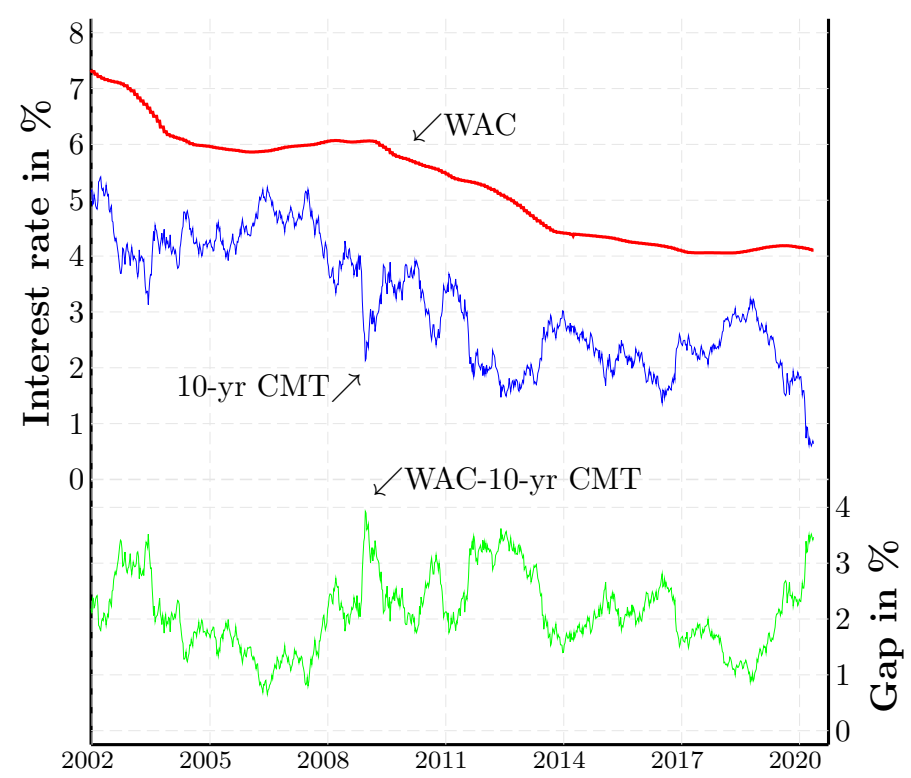

Notes: WAC is the weighted average coupon on an agency mortgage. A 10-yr CMT stands for the 10-year Treasury constant maturity rate. Source: JP Morgan

displaying the MBA refinance index, shows that despite these large refinancing incentives, borrowers are not refinancing as much as they have in previous periods of low rates. At the beginning of March, borrowers did refinance at historically high levels, but they have since settled down to a rate considerably lower than the peaks observed in the early 2010s and nowhere near the levels observed in the early 2000s. As mentioned above, negative equity was the friction preventing borrowers from refinancing in the 2010s. In contrast, the current friction preventing many borrowers from refinancing and taking advantage of low rates is employment/income loss. However, the logic behind the original HARP still holds. Fannie Mae, Freddie Mac, and Ginnie Mae already hold the credit risk, so allowing borrowers to streamline refinance without documenting employment and income will decrease rather than increase credit risk. 
Figure 3. Refinances and WAC

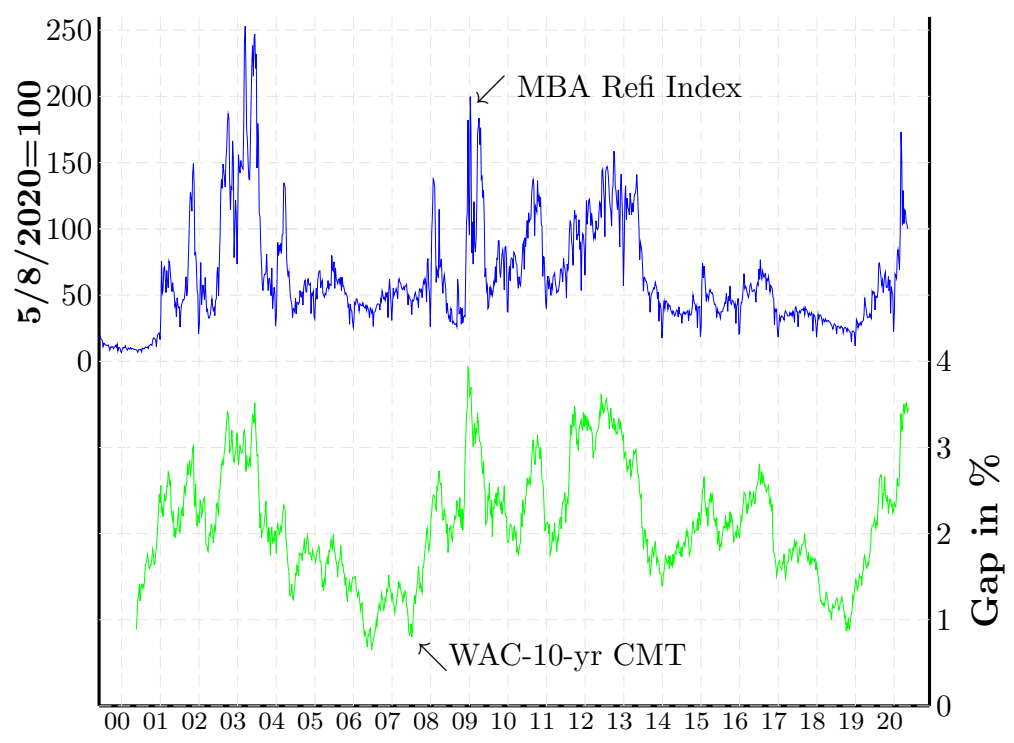

Notes: Refinance index comes from the MBA and is normalized to 100 for the most recent observation. WAC is the weighted average coupon on an agency mortgage. 10-yr CMT stands for the 10-year Treasury constant maturity rate.

\section{Data and Summary Statistics}

We conduct the analysis using a 1 percent sample of mortgages in the Black Knight McDash servicing database that are insured by either Fannie Mae, Freddie Mac, or Ginnie Mae, and that were reported to be active in February 2020 (the most recent month of data available to us) 12 The full force of the COVID-19 pandemic did not hit the United States until midto late March, and thus the equity distributions that we report below do not reflect any pandemic-related housing price dynamics, and the summary statistics do not account for borrowers who have refinanced since February.

Table 1 displays summary statistics for our mortgage sample. We separate Fannie Mae and Freddie Mac loans (panel A) from Ginnie Mae loans (panel B), as we conduct our analysis for the two loan types separately below. LTV is mark-to-market, which we calculate by using the most up-to-date reported loan balance and then updating the house value using the cumulative growth (since mortgage origination) in the corresponding CoreLogic county-level repeat sale price index 13

\footnotetext{
${ }^{12}$ After cleaning, we have 127,338 loans, of which 92,037 are Fannie Mae or Freddie Mac and 35,301 are Ginnie Mae.

${ }^{13}$ So far, there is little evidence of any significant decline in house prices due to the COVID-19 pandemic. A decline in house prices would, of course, alter this calculation.
} 
Table 1: Summary Statistics

Panel A: Fannie Mae and Freddie Mac Loans

\begin{tabular}{lc|cccccc}
\hline & Mean & $10 \%$ & $25 \%$ & $50 \%$ & $75 \%$ & $90 \%$ & $95 \%$ \\
\hline Loan Amount in thousand $\$$ & 184 & 65 & 101 & 162 & 246 & 336 & 386 \\
\hline LTV in \% & 50 & 25 & 36 & 50 & 64 & 76 & 82 \\
\hline Interest Rate in \% & 4.3 & 3.38 & 3.75 & 4.12 & 4.75 & 5.38 & 5.88 \\
30 year & 4.45 & 3.62 & 3.88 & 4.25 & 4.75 & 5.5 & 6 \\
15 year & 3.45 & 2.88 & 3 & 3.38 & 3.75 & 4.12 & 4.38 \\
\hline Monthly Payment in $\$$ & 1147 & 480 & 688 & 1026 & 1493 & 1957 & 2286 \\
\hline Loan Age (in months) & 71 & 21 & 37 & 66 & 91 & 124 & 172 \\
\hline
\end{tabular}

Panel B: Ginnie Mae Loans

\begin{tabular}{lc|cccccc}
\hline & Mean & $10 \%$ & $25 \%$ & $50 \%$ & $75 \%$ & $90 \%$ & $95 \%$ \\
\hline Loan Amount in thousand $\$$ & 158 & 65 & 93 & 135 & 199 & 278 & 343 \\
\hline LTV in \% & 64 & 42 & 52 & 65 & 77 & 86 & 91 \\
\hline Interest Rate in \% & 4.24 & 3.38 & 3.75 & 4 & 4.75 & 5.38 & 5.75 \\
30 year & 4.26 & 3.38 & 3.75 & 4.12 & 4.75 & 5.38 & 5.75 \\
15 year & 3.42 & 2.88 & 3 & 3.38 & 3.75 & 4 & 4.25 \\
\hline Monthly Payment in $\$$ & 903 & 420 & 573 & 792 & 1109 & 1519 & 1834 \\
\hline Loan Age (in months) & 73 & 22 & 40 & 72 & 98 & 124 & 139 \\
\hline
\end{tabular}

Notes: The underlying data is a 1 percent sample of active loans as of February 2020 in the Black Knight McDash servicing database. The sample is further restricted to 15- and 30-year fixed-rate mortgages with investor type equal to Fannie Mae or Freddie Mac (Panel A) and Ginnie Mae (Panel B). 
Three facts stand out in the table. First, most borrowers have significant equity in their homes. Both the mean and median Fannie Mae/Freddie Mac borrower have LTVs of only 50 percent, while 90 percent have LTVs less than 76 percent. The low LTV distribution reflects the fact that Fannie Mae/Freddie Mac LTVs are typically low at origination (FHA usually offers better rates for high LTV loans). In addition, as the bottom row in the panel shows, the median borrower has enjoyed more than five years of strong house price appreciation 14 While the mean and median Ginnie Mae borrowers have less equity relative to their Fannie/Freddie counterparts, they still have significant amounts in absolute terms (mean LTV of 64 percent and median LTV of 65 percent).

Second, table 1 shows that borrowers are paying high interest rates relative to what is available in the market. The MBA May 29, 2020, application survey shows conventional (that is, Fannie Mae/Freddie Mac) rates of 3.37 percent and 2.85 percent for 30- and 15year fixed-rate mortgages, respectively, and 3.46 percent for FHA 30-year fixed-rate loans, meaning that about 90 percent of the borrowers in our sample could get a lower rate and, for the median borrower, the reduction would be quite dramatic 15 The median 30-year fixedrate mortgage (FRM) borrower could get a rate almost 90 bps lower than they currently pay.

\section{Results}

We evaluate three potential refinance policies. The first is a HARP-like program that aims to minimize monthly payments while keeping loan balances constant. This program would unequivocally lower default risk. The second aims to increase household liquidity by allowing cash-out refis up to $90 \mathrm{LTV}$, which would raise default risk. The third program is a hybrid between the first two policies - a reduction in monthly payments and cash-out paymentsthat would hold the risk of default constant at pre-COVID-19 levels.

\section{Minimizing Monthly Payments}

The first policy follows the original HARP program quite closely and seeks to minimize monthly payments by refinancing borrowers into lower rates while keeping the mortgage

\footnotetext{
${ }^{14}$ House price appreciation has, thus far, continued during the COVID-19 pandemic. For example, the Case-Shiller 20-City Composite Index increased from 219.86 in February to 222.21 in March (https://us.spi ndices/indicators/sp-corelogic-case-shiller-20-city-composite-home-price-nsa-index\#overview.)

${ }^{15}$ The MBA survey produces an index rate slightly different from the index rate produced by the Freddie Mac survey mentioned in the introduction, but we use the MBA here because it includes FHA loans. It is also important to note that there is no risk-based pricing in the FHA and VA programs. There are loanlevel pricing adjustments (LLPAs) for GSE mortgages that borrowers with relatively lower credit scores and higher LTV ratios typically have to pay; however, we assume that these LLPAs would not be applied to the streamlined program that we consider below.
} 
balances constant. Borrowers refinance into the same type of loan they had previously (15-year FRM to 15-year FRM) and do not receive any cash-out payment. We set the interest rates to $r_{30}=3.3$ percent and $r_{15}=2.8$ percent for 30-year and 15-year mortgages (roughly consistent with the Freddie Mac survey at the end of May 2020). We consider two different assumptions with respect to the maturity of the new loans. First, we assume that the maturity is reset to its original value, so that a 30-year FRM with a term of 22 years remaining is reset to 30 years. In a second set of calculations, we assume that the loan maturities are not recast but are instead set at the values of the remaining terms (that is, a 30-year FRM with a term of 22 years remaining is refinanced into a FRM with a 22-year maturity). Finally, we assume, as with the HARP program, that there are no closing costs, borrowers need not document income or assets, and there is no cap on the LTV ratio.

We display the effects of this refinance program on the distribution of monthly payments in the first row of tables 2 and 3 in columns (1) through (3) for Fannie Mae/Freddie Mac and Ginnie Mae borrowers, respectively. Panel A in each table assumes that the maturities are recast, while panel $\mathrm{B}$ holds the maturities constant. In panel $\mathrm{A}$ of table 2 , the mean Fannie Mae/Freddie Mac borrower receives a monthly payment reduction of just over $\$ 280$. The distribution is slightly skewed, as the median borrower receives less $(\$ 230)$ while 10 percent of borrowers receive a reduction of more than $\$ 520$. In panel $\mathrm{B}$, we see that the payment reductions are significantly smaller when the maturities are not reset, which is not surprising given the high average age of the loan in our sample (see the bottom row in panel A of table 1). In this scenario, the median payment reduction is only $\$ 78$, while the mean is $\$ 97$.

In table 3 we see that the payment reductions are lower for Ginnie Mae borrowers. Assuming that maturities are recast, the mean (median) Ginnie Mae borrower is able to lower their payment by $\$ 197$ (\$162). When maturities are held constant, average (median) payment decrease by $\$ 73(\$ 58)$. The lower payment reductions for Ginnie Mae loans are the result of two factors, which can be seen in table 1; lower initial principal balances and lower initial rates.

In addition to providing increased cash flow for borrowers, refinancing affects default risk, which matters to both borrowers and lenders. We estimate the effect of refinancing on default risk by using estimates from Fuster and Willen (2017) to build a very simple model of default 16 Roughly, our model says that a 1 percentage point reduction in the ratio of monthly payment to loan balance reduces the default hazard 30 percent (that is, from 1 to 0.7), and a 10 percentage point increase in LTV increases the default hazard by about 19

\footnotetext{
${ }^{16}$ Fuster and Willen (2017) estimate the treatment effect of payment changes by focusing on a sample of borrowers who received large payment reductions when payments on their adjustable rate mortgages fell in 2010. They also estimate the effect of LTV by measuring the differences in default hazards for borrowers with different mark-to-market LTVs while controlling for origination LTV.
} 
Table 2: Summary of Streamlined Refinance Experiments: Fannie Mae and Freddie Mac Loans

\begin{tabular}{|c|c|c|c|c|c|c|c|c|c|}
\hline \multicolumn{10}{|c|}{$\begin{array}{l}\text { Panel A: Assume Full Recast of Loan to Original Term } \\
\text { Borrower with 30-year (15-year) refinances into new 30-year (15-year) }\end{array}$} \\
\hline & \multicolumn{3}{|c|}{$\begin{array}{l}\text { Payment Change } \\
\text { (in } \$ / \text { month) }\end{array}$} & \multicolumn{3}{|c|}{$\begin{array}{c}\text { Cash Out } \\
\text { (in thousands of } \\
\$ \text { ) }\end{array}$} & \multicolumn{3}{|c|}{$\begin{array}{l}\text { Default Hazard } \\
\text { (relative to base) }\end{array}$} \\
\hline & Mean & Median & $90 \%$ & Mean & Median & $90 \%$ & Mean & Median & $90 \%$ \\
\hline $\begin{array}{l}\text { (1) Minimum } \\
\text { Payment }\end{array}$ & -283 & -229 & -522 & - & - & - & 0.56 & 0.63 & 0.78 \\
\hline $\begin{array}{l}\text { (2) Max } \\
\text { Cash Out }\end{array}$ & - & - & - & 54.3 & 45.6 & 101.7 & 1.31 & 1.27 & 1.63 \\
\hline $\begin{array}{l}\text { (3) Iso- } \\
\text { default }\end{array}$ & -96 & -80 & -174 & 37.8 & 30.4 & 73.0 & - & - & - \\
\hline $\begin{array}{l}(3 \mathrm{a}) r_{30}=2.5 \% \\
r_{15}=2.0 \%\end{array}$ & -136 & -117 & -244 & 50.8 & 43.1 & 93.2 & - & - & - \\
\hline
\end{tabular}

Panel B: Assume No Change in Termination Date

Borrower with 16 years left on 30-mortgage refinances into 16-year mortgage.

\begin{tabular}{|c|c|c|c|c|c|c|c|c|c|}
\hline & \multicolumn{3}{|c|}{$\begin{array}{l}\text { Payment Change } \\
\text { (in } \$ / \text { month) }\end{array}$} & \multicolumn{3}{|c|}{$\begin{array}{c}\text { Cash Out } \\
\text { (in thousands of } \\
\$ \text { ) }\end{array}$} & \multicolumn{3}{|c|}{$\begin{array}{l}\text { Default Hazard } \\
\text { (relative to base) }\end{array}$} \\
\hline & Mean & Median & $90 \%$ & Mean & Median & $90 \%$ & Mean & Median & $90 \%$ \\
\hline $\begin{array}{l}\text { (1) Minimum } \\
\text { Payment }\end{array}$ & -97 & -78 & -199 & - & - & - & 0.82 & 0.83 & 0.94 \\
\hline $\begin{array}{l}\text { (2) Max } \\
\text { Cash Out }\end{array}$ & - & - & - & 16.5 & 12.9 & 35.4 & 1.09 & 1.08 & 1.21 \\
\hline $\begin{array}{l}\text { (3) Iso- } \\
\text { default }\end{array}$ & -37 & -24 & -81 & 11.1 & 8.9 & 23.1 & - & - & - \\
\hline $\begin{array}{l}(3 \mathrm{a}) r_{30}=2.5 \% \\
r_{15}=2.0 \%\end{array}$ & -69 & -49 & -143 & 20.9 & 17.9 & 40.0 & - & - & - \\
\hline
\end{tabular}

Notes: In the baseline calculations, borrowers with 30-year fixed-rate mortgages refinance at $r_{30}=3.3$ percent and those with 15-year fixed-rate mortgages refinance at $r_{15}=2.5$ percent. Source 
Table 3: Summary of Streamlined Refinance Experiments: Ginnie Mae Loans

\begin{tabular}{|c|c|c|c|c|c|c|c|c|c|}
\hline \multicolumn{10}{|c|}{$\begin{array}{c}\text { Panel A: Assume Full Recast of Loan to Original Term } \\
\text { Borrower with 30-year (15-year) refinances into new 30-year (15-year) }\end{array}$} \\
\hline & \multicolumn{3}{|c|}{$\begin{array}{l}\text { Payment Change } \\
\text { (in } \$ / \text { month) }\end{array}$} & \multicolumn{3}{|c|}{$\begin{array}{l}\text { Cash Out } \\
\text { (in thousands of } \\
\$ \text { ) }\end{array}$} & \multicolumn{3}{|c|}{$\begin{array}{l}\text { Default Hazard } \\
\text { (relative to base) }\end{array}$} \\
\hline & Mean & Median & $90 \%$ & Mean & Median & $90 \%$ & Mean & Median & $90 \%$ \\
\hline $\begin{array}{l}\text { (1) Minimum } \\
\text { Payment }\end{array}$ & -197 & -162 & -359 & - & - & - & 0.62 & 0.67 & 0.82 \\
\hline $\begin{array}{l}\text { (2) Max } \\
\text { Cash Out }\end{array}$ & - & - & - & 35.0 & 29.5 & 70.5 & 1.26 & 1.26 & 1.65 \\
\hline $\begin{array}{l}\text { (3) Iso- } \\
\text { default }\end{array}$ & -93 & -73 & -176 & 22.9 & 18.7 & 47.4 & - & - & - \\
\hline $\begin{array}{l}\text { (3a) } r_{30}=2.5 \% \\
r_{15}=2.0 \%\end{array}$ & -138 & -110 & -256 & 31.2 & 27.0 & 60.9 & - & - & - \\
\hline
\end{tabular}

Panel B: Assume No Change in Termination Date

Borrower with 16 years left on 30-mortgage refinances into 16-year mortgage.

\begin{tabular}{lccc|ccc|ccc}
\hline & \multicolumn{2}{c|}{$\begin{array}{c}\text { Payment Change } \\
\text { (in \$/month) }\end{array}$} & \multicolumn{3}{c|}{$\begin{array}{c}\text { Cash Out } \\
\text { (in thousands of } \\
\text { Mean }\end{array}$} & \multicolumn{3}{c}{$\begin{array}{c}\text { Default Hazard } \\
\text { (relative to base) }\end{array}$} \\
& -73 & -58 & -153 & - & - & - & 0.84 & 0.86 & 0.99 \\
\hline $\begin{array}{l}\text { (1) Minimum } \\
\text { Payment }\end{array}$ & - & - & - & 9.8 & 8.4 & 22.3 & 1.06 & 1.07 & 1.20 \\
\hline $\begin{array}{l}\text { (2) Max } \\
\text { Cash Out }\end{array}$ & -38 & -21 & -81 & 6.3 & 5.5 & 14.6 & - & - & - \\
\hline $\begin{array}{l}\text { (3) Iso- } \\
\text { default } \\
\begin{array}{l}(3 \mathrm{a}) r_{30}=2.5 \%, \\
r_{15}=2.0 \%\end{array}\end{array}$ & -73 & -47 & -155 & 13.1 & 12.0 & 25.2 & - & - & - \\
\hline
\end{tabular}

Notes: In the baseline calculations, borrowers with 30-year FRMs refinance at $r_{30}=3.3$ percent and those with 15-year FRMs refinance at $r_{15}=2.5$ percent. 
percent (for example, from 1 to 1.19) 17

Columns ( 7 through 9 ) in the first row of tables 2 and 3 show the change in the distribution of monthly default hazards from the HARP-like refinance policy. When we assume that maturities are reset, default risk associated with both the mean and median Fannie Mae/Freddie Mac mortgage falls by about 40 percent. If we do not recast the maturities, the decline in default risk is lower, since the monthly payments do not decrease by nearly as much. In that case, the default hazard of the median (mean) Fannie Mae/Freddie Mac loan decreases by 17 percent (18 percent). The corresponding default hazard effects for Ginnie Mae loans displayed in table 3 are slightly smaller since the payment declines are smaller. The mean (median) Ginnie loan experiences a 38 percent (33 percent) decline in the default hazard when maturities are recast and a 16 percent (14 percent) decline when maturities are held constant.

\section{Maximizing Cash-Out Payments}

In a more traditional economic contraction, a $\$ 280$ increase in spending power might be an effective tool once it is magnified by an appropriate multiplier. However, in the current situation, the value of a flow payment reduction might be more limited. Given the severe restrictions on economic activity, many households simply cannot spend more, so $\$ 280$ would have little to no effect. At the same time, other households cannot supply basic subsistence needs, so $\$ 280$ would not help much. To address this, we consider, as shown in row (2) of tables 2 and 3, a second experiment in which we maximize household cash by keeping the monthly payment the same and using the reduced interest rate to increase the loan balance and generate cash-out payments. This experiment deviates from the original HARP and the VA's IRRRL program, which did not allow any cash-out payment, as well as from the SLR program, which caps cash-out at $\$ 500$. We allow borrowers to extract equity until their LTV reaches 90 percent 18 Again, we reset loan maturities back to their initial levels in panel A, while we hold maturities constant in panel B. We report statistics from the distribution of maximum cash-out amounts in columns (4) through (6) and the distribution of the change in default hazards in columns (7) through (9).

We estimate that the average (median) household in the Fannie Mae/Freddie Mac sample could take out a maximum of $\$ 54,300(\$ 45,600)$. However, most of this is driven by extended amortization, as the effect of the interest rate alone, shown in panel B of table 2, is only $\$ 16,500$ (\$12,900). The cash-out numbers are lower across the board for the Ginnie Mae

\footnotetext{
${ }^{17}$ Further details are located in the appendix.

${ }^{18}$ LTVs of 90 are not uncommon, especially for FHA borrowers. Although there is a concern that such a high LTV has less of a cushion against declines in house prices, so far during the COVID-19 pandemic, house prices have continued to rise (see footnote 14).
} 
borrowers. According to table 3, the average (median) household in the Ginnie Mae sample could take out $\$ 35,000(\$ 29,500)$ if maturities are recast, and $\$ 9,800(\$ 8,400)$ if maturities are held constant.

While generating substantial resources for borrowers, this cash-out maximizing plan leads to substantial increases in default risk. Under the maturity reset policy, the default hazard associated with the average Fannie Mae/Freddie Mac (Ginnie Mae) loan increases more than 30 percent ( 25 percent). The tables makes it clear that the greater the benefit to the borrower, the greater the increase in default risk, as the average default hazard increases by more than 60 percent for the 10 percent of Fannie/Freddie borrowers who could take more than $\$ 100,000$ in cash-out payments. Thus, there is a reasonable argument that such a plan goes against the basic idea that the government agencies should ignore the risks because they already hold them. 19

\section{An Iso-Default Policy}

The third and final policy experiment that we evaluate is a hybrid between the first two policies. In this experiment, we calculate what we call the "iso-default" level of cash-out payments that keeps default risk constant for each borrower. Since default risk is monotonically increasing in leverage and decreasing in payment size, the iso-default level of cash-out payments will always be lower than the maximum amount that we calculated under the previous policy experiment. Table 2 shows that minimizing the payment reduces default risk by about 40 percent for the median Fannie Mae/Freddie Mac loan. Our model says that a 10 percentage point increase in LTV increases the default hazard by about 20 percent. To be sure, the increase in loan balance also increases the payment and the default rate. However, as row (3) of table 2 shows, the median Fannie Mae/Freddie Mac borrower can reduce payments by about $\$ 80$ per month and take out more than $\$ 30,000$ in cash without increasing default risk for Fannie Mae and Freddie Mac. Row (3) of table 3 shows that the median Ginnie Mae borrower can take out almost $\$ 19,000$ in cash and reduce payments by just over $\$ 70$ without an increase in default risk 20

\footnotetext{
${ }^{19}$ There is also a concern that borrowers could "strategically" choose to use the extracted funds for purposes other than making their mortgage payments, leaving the GSEs and FHA/VA on the hook for the higher principal balance. However, we think the risk of this is small. As discussed in the introduction, all evidence points to borrowers making their mortgage payments even when doing so is not in their best interest.

${ }^{20}$ While default risk is constant, the effect on profitability is ambiguous and depends on the size of the guarantee fee and the level of expected flow losses on the loan.
} 


\section{Discussion}

One aspect of the above analysis that is worth spending a bit more discussion on is what to assume about the interest rate that borrowers in a streamlined refinance plan could obtain 21 In our baseline specification, we assume that borrowers pay a rate roughly equal to the Freddie Mac Primary Market Survey rate. But one argument for the unusually wide spread between the primary and secondary mortgage rates is that lenders are concerned about the potential for income loss and forbearance due to the COVID-19 pandemic. Fannie and Freddie insure all credit losses, but there are still large risks for lenders in the securitization process, particularly related to the possibility that the borrower will enter forbearance before Fannie and Freddie or Ginnie purchase the loan.

Figure 4 shows that the primary-secondary spread grew from 100 basis points before the emergence of COVID-19 in mid-February to almost 200 basis points after forbearance became a first-order issue for lenders. A HARP-type refinance program would relieve originators of any risks associated with forbearance and, potentially, could reduce the primary-secondary spread. The line labeled "counterfactual" in the figure shows what the 30-year rate would be if the primary-secondary spread remained at 2019 levels 22 Row (3a) of both panels in tables 2 and 3 shows the benefits of the iso-default plan with the lower counterfactual rates (2.5 percent for 30-year FRMs and 2.0 percent for 15-year FRMs). If the maturities are reset, the median Fannie Mae/Freddie Mac borrower would obtain a $\$ 117$ monthly payment reduction (compared with $\$ 80$ ) and would be able to take out about $\$ 43,000$ in cash-out (compared with $\$ 30,000)$. The median Ginnie Mae borrower would obtain a $\$ 110$ payment reduction (compared with $\$ 73$ ) and could take out $\$ 27,000$ in cash-out (compared with $\$ 18,700$ ).

It would also be of interest to understand the potential welfare gains of these various programs. While our iso-default policy would keep default risk constant at its pre-COVID-19 levels, it is possible that the welfare gains to borrowers from being able to extract additional equity would offset an increase in default risk. Especially if a streamlined refinance program were already in place ex-ante, it could act as an automatic stabilizer for existing homeowners and therefore prevent the need for action by Congress. Unfortunately, while of interest, answering this question would require a model and is therefore beyond the scope of this paper.

\footnotetext{
${ }^{21}$ We abstract from the general equilibrium effects on the demand for mortgage credit on the grounds that the total volume of new debt will be small relative to the market.

${ }^{22} \mathrm{We}$ also calculate the counterfactual rate assuming that the primary-secondary spread equaled its average level in 2018 and find virtually identical results.
} 
Figure 4. Decomposition of the Evolution of the Conforming Mortgage Rate.

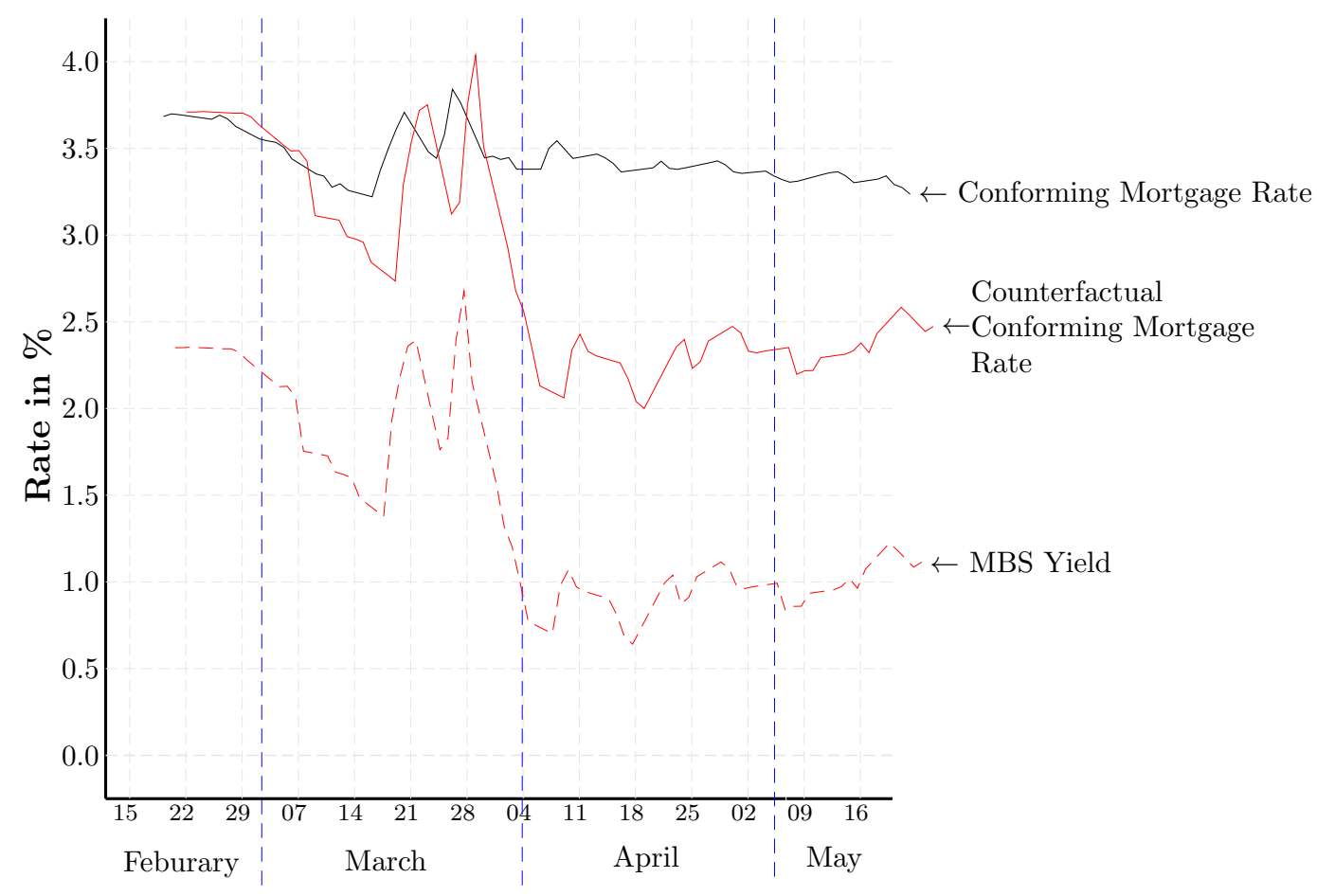

Notes: Conforming Mortgage Rate is the average rate associated with loans below the conforming loan limit and is taken from Optimal Blue (https://www2.optimalblue.com/obmmi/). MBS Yield is the Current Coupon in the TBA (to-be-announced) market. The Counterfactual Conforming Mortgage Rate is calculated by taking the MBS yield and adding the average 2019 primary-secondary spread, defined here as the spread between the MBS Yields and the conforming mortgage rate. 


\section{Conclusion}

Recent turmoil in labor markets from the COVID-19 pandemic has made it difficult for many mortgage borrowers experiencing financial distress to refinance into the prevailing, historically low market rates. In addition, it is even more difficult for these borrowers to access the significant amounts of housing equity that many have accumulated from recent years of robust house price growth. This article evaluates a streamlined refinance program in the spirit of HARP that would allow households with government-insured loans to refinance into lower rates without needing to document income or employment. We consider a straight rate-refi program that minimizes payments while holding the loan balance constant as well as a cash-out program that maximizes equity extraction while holding the payment fixed. Finally, we consider a hybrid program that both lowers payments and allows for cash-out payments but keeps default risk constant.

We find large potential payment savings for Fannie Mae, Freddie Mac, and Ginnie Mae borrowers from a HARP-like rate- refinance program. The average Fannie Mae/Freddie Mac borrower could save approximately $\$ 280$, while the average Ginnie Mae borrower could save almost $\$ 200$ per month. These monthly savings would, in turn, lead to substantial declines in default risk. Including a cash-out component but restricting the amount of equity extraction to keep default risk constant results in a lower but nontrivial payment decline and a substantial cash windfall that could be used to help financially distressed borrowers smooth consumption. For example, under the hybrid plan, we estimate that the median Fannie Mae/Freddie Mac borrower could reduce payments by $\$ 80$ per month and extract more than $\$ 30,000$ in equity. Such a program could be used as an alternative to

forbearance, with the advantage being that borrowers would not need to become delinquent on payments. 


\section{References}

Abel, J. and A. Fuster (2019). How do mortgage refinances affect debt, default, and spending? evidence from harp. American Economic Journal: Macroeconomics Forthcoming.

Agarwal, S., G. Amromin, S. Chomsisengphet, T. Piskorski, A. Seru, and V. Yao (2015). Mortgage refinancing, consumer spending, and competition: Evidence from the home affordable refinancing program. Technical report, NBER Working Paper 21512.

deFusco, A. and J. Mandragon. No job, no money, no refi: Frictions to refinancing in a recession. Journal of Finance Forthcoming.

Di Maggio, M., A. Kermani, B. J. Keys, T. Piskorski, R. Ramcharan, A. Seru, and V. Yao (2017). Interest rate pass-through: Mortgage rates, household consumption, and voluntary deleveraging. American Economic Review 107(11), 3550-88.

Fuster, A. and P. Willen (2017). Payment size, negative equity, and mortgage default. American Economic Journal: Economic Policy 9(4), 167-191.

Gerardi, K., K. F. Herkenhoff, L. E. Ohanian, and P. S. Willen (2018). Can't pay or won't pay? unemployment, negative equity, and strategic default. The Review of Financial Studies 31(3), 1098-1131.

Gupta, A. and C. Hansman (2019). Selection, leverage, and default in the mortgage market. Available at SSRN 3315896.

Karamon, K., D. McManus, and J. Zhu (2017). Refinance and mortgage default: A regression discontinuity analysis of harp's impact on default rates. The Journal of Real Estate Finance and Economics 55(4), 457-475. 


\section{Appendix}

In this appendix, we show the details of the mapping that we develop between monthly mortgage payment changes and changes in default risk. The mapping is based on the analysis of Fuster and Willen (2017), which estimates the causal effect of payment reductions on default probabilities using variation created by contractually specified downward rate resets in a sample of interest-only, nonagency adjustable-rate mortgages originated in the 200506 period. We also use Fuster and Willen's estimates of the sensitivity of default risk to cross-sectional variation in LTV ratios to develop a mapping between LTVs and default hazards. However, those estimates are not causal in nature and thus should be interpreted with caution. 23

We start with a log default hazard function:

$$
\log \left(P_{i}(d)\right)=\alpha_{i}+\beta_{\pi} \pi_{i}+\beta_{L} L T V_{i}
$$

where $P_{i}(d)$ is the probability of default for loan $i, \pi_{i}$ is the mortgage $i$ 's interest rate, and $L T V_{i}$ is mortgage $i$ 's LTV ratio, which is equal to $L_{i} / V_{i}$, the principal balance of the loan over the value of underlying collateral.

Using column 1 of Table A.1 Fuster and Willen (2017), we can calculate approximate values of $\beta_{\pi}$ and $\beta_{L}$ as follows. Reducing the interest rate 4 percentage points, holding LTV constant multiplies the default hazard by a factor of 0.3 , which implies that:

$$
\begin{aligned}
\log \left(P_{i}(d) \mid \pi^{\prime}\right)-\log \left(P_{i}(d) \mid \pi\right) & =\beta_{\pi}\left(\pi_{i}^{\prime}-\pi_{i}\right) \\
\log (0.3)-\log (1) & =\beta_{\pi} \cdot-.04 \\
\beta_{\pi} & =\frac{\log (0.3)}{0.04}=30
\end{aligned}
$$

Holding $\pi$ constant, increasing LTV from 0.85 to 1.05 increases the default probability by $.585 / .401 \mathrm{so}$

$$
\begin{aligned}
\log \left(P_{i}(d) \mid L T V^{\prime}\right) & -\log \left(P_{i}(d) \mid L T V\right) \\
& =\beta_{L}\left(L T V_{i}^{\prime}-L T V_{i}\right) \\
\log (.585)-\log (0.401) & =\beta_{L} \cdot 0.2 \\
\beta_{L} & =\frac{\log (1.45)}{0.2}=1.885
\end{aligned}
$$

\footnotetext{
${ }^{23}$ For a discussion of estimating the treatment effects of LTV changes, see Gupta and Hansman (2019).
} 
Using the definition of LTV and $\pi$ we transform equation (1):

$$
\log (p)_{i}=\alpha+\beta_{L, i} L_{i}+\beta_{\pi, i} \cdot \pi L_{i}
$$

where $\beta_{L_{i}} \equiv \beta_{L} / V_{i}$ and $\beta_{\pi_{i}} \equiv \beta_{\pi} / L_{i}$. The transformation means that equation (2) measures the effect on default of the loan balance (not the LTV) and the monthly payment in dollars (not as a percentage of the loan balance).

Suppose we start with $\pi_{0}$ and $L_{0}$ and assume that $L_{i}=L_{0}$ and $V_{i}=V$ so $\beta_{\pi, i}=\beta_{\pi} / L_{0}$ and $\beta_{L, i}=\beta_{L} / V$. Suppose a loan leads to annuity factor $\pi_{N}$ and loan balance $L_{N}$. Then taking differences of equation (2) yields:

$$
\begin{aligned}
\log (p)_{N}-\log (p)_{0} & =\frac{\beta_{L}}{V}\left(L_{N}-L_{0}\right)+\frac{\beta_{\pi}}{L_{0}}\left(\pi_{N} L_{N}-\pi_{0} L_{0}\right) \\
& =\left(\frac{\beta_{L}}{V}+\frac{\beta_{\pi}}{L_{0}} \pi_{N}\right)\left(L_{N}-L_{0}\right)+\beta_{\pi} \cdot\left(\pi_{N}-\pi_{0}\right)
\end{aligned}
$$

Assume interest rates fall $\left(\pi_{N}<\pi_{0}\right)$. We can now consider three policies.

1. Increase the balance to keep monthly payment constant (that is, $\pi_{N} L_{N}=\pi_{0} L_{0}$ ),

$$
\log (p)_{N}-\log (p)_{0}=\frac{\beta_{L}}{V}\left(L_{N}-L_{0}\right)=\frac{\beta_{L} L_{0}}{V \pi_{N}}\left(\pi_{0}-\pi_{N}\right)
$$

Payment stays the same and $L T V$ goes up, so default goes up.

2. No change in balance

$$
\log (p)_{N}-\log (p)_{0}=\beta_{\pi} \cdot\left(\pi_{N}-\pi_{0}\right)
$$

LTV stays the same and payment goes down, so default goes down.

3. Increase balance just enough to maintain default rate. Set

$$
L_{N}^{*}=L_{0}+\frac{\beta_{\pi}}{\frac{\beta_{L}}{V}+\frac{\beta_{\pi}}{L_{0}} \pi_{N}}\left(\pi_{0}-\pi_{N}\right)
$$

then $P_{N}-P_{0}=0$. In $L T V$ terms,

$$
L T V_{N}^{*}=L T V_{0}+\frac{\pi_{0}-\pi_{N}}{\frac{\beta_{L}}{\beta_{\pi}}+\frac{\pi_{N}}{L T V_{0}}}
$$

